\title{
OS INQUIETANTES E INSÓLITOS ANJOS LATINO-AMERICANOS
}

\author{
Marisa Martins Gama-Khalil ${ }^{1}$
}

Resumo: 0 artigo tem como proposta a discussão da noção de real maraviIhoso, uma das vertentes da literatura fantástica, por intermédio da análise de dois contos de autores latino-americanos: "Um senhor muito velho com umas asas enormes", de Gabriel García Márquez, e "Um moço muito bran- co", de João Guimarães Rosa.

Palavras-Chave: Literatura fantástica, Real maravilhoso, Anjos.

Resumen: El artículo tiene como objetivo discutir la noción de real maravilloso, una de las vertientes de la literatura fantástica, a través del análisis de dos cuentos de autores latinoamericanos: "Um senhor muito velho com $\mathrm{u}$ - mas asas enormes", de Gabriel García Márquez, y "Um moço muito branco", de João Guimarães Rosa.

Palabras-Clave: Literatura fantástica, Real maravilloso, Ángeles.

\section{PALAVRAS INICIAIS:}

\section{SOBRE ESSA ESTRANHA LITERATURA NA AMÉRICA DOS MIRABILIA}

Mas o que é a história da América toda senão uma crônica do real maraviIhoso? (Alejo Carpentier, 2009, p. 12).

Durante muito tempo os leitores viram irromper das metrópoles europeias, especialmente de Paris, as grandes revoluções artísticas, que ditaram tendências estéticas, reorganizaram formas de ler e de portar-se diante do objeto de arte. Em meados do século XX, contudo, a América Latina experimentou o lugar de fomentadora e difusora de uma ampla revolução literária. Esteve ligada a ela, segundo maior parte da crítica literária, auto- res como Gabriel García Márquez, Julio Cortázar, Mario Vargas Llosa, Carlos Fuentes, Juan Rulfo.

Muita polêmica, no entanto, marca os estudos sobre o boom da literatura latino-americana. Qual foi o seu alcance? Que legado estético deixou

${ }^{1}$ Professora Doutora em Estudos Literários pela Universidade Estadual Paulista Júlio de Mesquita Filho; Docente do Instituto de Letras e Linguística da Universidade Federal de Uberlândia (UFU); Pesquisadora do CNPq; líder do Grupo de Pesquisas em Espacialidades Artísticas. Endereço eletrônico: marisa.gamakhalil@pq.cnpq.br. 
ao campo da arte? Se todos os experimentos literários passaram de fato ou se marcam a literatura que hoje é escrita? Que autores foram os representantes maiores desse boom. Qual a terminologia mais adequada para designar essa literatura: realismo mágico, real maravilhoso ou realismo maravilhoso? Haverá o pós-boom?

É ponto comum entre os estudiosos do tema que essa revolução da literatura latino-americana significou amplamente, em termos estéticos, a crise do realismo, conforme atesta Irlemar Chiampi (1980), e que a proposta dos autores que produziam em diversos espaços das Américas Central e do Sul era:

\begin{abstract}
criar uma literatura, e, sobretudo, uma narrativa, que focalizasse a crise do homem americano numa sociedade complexa que, ao mesmo tempo em que desejava ingressar na era industrial e tecnológica e seu universo urbano, ainda vivia em um mundo rural e agrário, salpicado por relações econômicas e sociais medievais, num período em que a Europa discutia formas de superação do capitalismo (ESTEVES; FIGUEIREDO, 2010, p. 394).
\end{abstract}

Por meio da experiência apreendida com os princípios das vanguardas europeias e com os postulados modernistas que reviam e deslocavam os paradigmas da escrita literária realista, os escritores latino-americanos delinearam, através de suas obras, um outro lugar para o real, um real deslocado de utopias, caracterizadas pelos ingênuos desejos de similitudes. 0 lúdico e o parodístico, de acordo com Chiampi (1980), serão as novas chaves para o ingresso nesse real deslocado. Percebo que o resultado foi o de uma arte que, em meu ponto de vista, pauta seus princípios criativos em uma certa hiperbolização do procedimento da singularização ou estranha- mento, nos termos expostos por Victor Chklóvski (1978). Essa aventura por uma hiperbolização do estranhamento significava imprimir uma escrita que projetava imagens - usualmente prosaicas - de forma que estas se apresentassem aos leitores como jamais vistas, nunca experimentadas pela percepção. Em meu entendimento, tais deslocamentos propiciaram o maraviIhoso jogo entre os realia e os mirabilia, colocando em cena um novo "modo" fantástico. A perspectiva adotada neste estudo é a do entendimen- to da literatura fantástica pelo mirante do modo e não do gênero. A base desse mirante sustenta-se especialmente na proposta de Irène Bessière (2001) e de Filipe Furtado (2011). O teórico português, Furtado, no E- dicionário de Termos literários (2011), considera que diante da vasta hete- rogeneidade de narrativas que se inserem no campo da literatura fantásti- 
ca, é pertinente considerar com atenção os elementos que invariavelmente nelas aparecem e, como consequência, a sua adesão ao modo fantástico.

Com uma produção latino-americana que "afrontava" os fundamentos estéticos do cânone em voga, a crítica literária viu a necessidade de compreender essa nova experiência literária e, nessa conjuntura, foram sendo usados os termos realismo mágico e realismo maravilhoso.

Há inúmeros trabalhos que tratam da emergência da literatura lati- noamericana a partir da segunda metade do século $X X$, porém verifico que grande parte deles não situa a literatura brasileira nesse momento de boom, ou seja, é como se o Brasil estivesse à margem da América Latina e, consequentemente, desse momento frutuoso vivido por ela. Tenho a consciência de que há muitas razões que parecem mover essa exclusão, uma delas é, por exemplo, a condição linguística, uma vez que não falamos a língua espanhola, a de maior circulação nesta parte do continente. Entretanto, mesmo assim, inquieta-me, nos referidos estudos, a regulada marginalização da literatura brasileira, na medida em que as narrativas literárias aqui produzidas acompanham a mesma tendência (e qualidade) estética produzida por autores de outros países das Américas do Sul e Central. A estudiosa Bella Josef, por exemplo, em alguns estudos, exclui a literatura brasileira, conforme se pode perceber em "A nova realidade do romance hispano-americano" (JOSEF, 1993); já em outros, inclui alguns autores brasileiros, como Clarice Lispector e José J. Veiga, no conjunto das tendências da nova narrativa fantástica, como em A máscara e o enigma (JOSEF, 1986). O subtítulo do livro $O$ realismo maravilhoso da pesquisadora Irlemar Chiampi (1980), "Forma e ideologia no romance hispano-americano", já dá mostras da não inserção da literatura brasileira nas discussões atinentes ao supracitado boom. É imprescindível ressaltar que o livro de Chiampi é um dos mais importantes estudos sobre o realismo maravilhoso no circuito acadêmico brasileiro e latino-americano, e infelizmente essa exclusão da literatura brasileira reforça a ideia, entre os pesquisadores iniciantes, de que os nossos autores não tenham contribuído para a revolução provocada pela literatura latino-americana no século XX. Já o estudo de Antonio Roberto Esteves e Eurídice Figueiredo (2010), "Realismo mágico e Realismo maravilhoso", traz a literatura brasileira marcada como expressão importante no boom da literatura latino-americana, através da escrita do mineiro João Guimarães Rosa.

Julio Cortázar, um dos autores que, de acordo com a historiografia e crítica literárias, integram o conjunto de autores responsáveis pela o boom 
latino-americano, reconhece a importância da literatura brasileira na tessitura de suas obras. Em entrevista a Remy Gorga Filho, manifesta declaradamente essas ideias. Conta-nos Remy Gorja Filho: "Ele gostava de conversar e falava muito sobre a Clarice Lispector [...]. Ele dizia que o mineiro Murilo Rubião foi o primeiro autor do fantástico latino-americano, antes mesmo dele, Cortázar" (apud SILVEIRA, 2012).

Neste estudo, mostrarei como a escrita literária do brasileiro João Guimarães Rosa e do colombiano Gabriel García Márquez terão muitos pontos de sintonia relacionados ao ludismo no trabalho coma representação deslocada e singularizada dos realia e dos mirabilia.

\section{O ESPAÇO DOS MIRABILIA E A POLÊMICA DOS TERMOS: REALISMO MÁGICO, REALISMO MARAVILHOSO, REAL MARAVILHOSO?}

Para explicar a literatura latino-americana que revolucionou o século $X X$, os termos realismo mágico e realismo maravilhoso, "mais que concei- tos, seriam rótulos usados de forma mais ou menos indiscriminada, às vezes alternando-se, às vezes opondo-se, às vezes complementando-se" (ESTEVES; FIGUEIREDO, 2010, p. 395).

Não é o foco principal deste estudo historicizar as condições de emergência e de circulação dos termos, contudo a questão interessa no sentido de situar os contos de García Márquez ("Um senhor muito velho com umas asas enormes") e de Guimarães Rosa ("Um moço muito branco") nessas tendências. Por esse motivo, não farei uma recuperação tão detalhada da irrupção dos termos na história da crítica literária, mas me deterei na categorização estética dos mesmos. Para tanto, tomarei como referência sobretudo os estudos de Antonio Roberto Esteves e Eurídice Figueiredo (2010), de Irlemar Chiampi (1980, p. 23), bem como dos ensaios do escritor Alejo Carpentier (1987; 2009).

Um fato curioso é que o termo realismo mágico foi usado pela primeira vez por Franz Roh para a compreensão da arte europeia, seja em artigo, publicado em 1923, sobre o expressionismo alemão, seja em estudo, datado de 1925, sobre o pós-expressionismo na pintura europeia. Franz Roh assim se expressa sobre a particularidade estética do realismo mágico: "representar as coisas concretas e palpáveis, para tornar visível o mistério que ocultam" (apud ESTEVES; FIGUEIREDO, 2010, p. 396). Ainda na Europa e sobre a arte europeia, em 1926, Massimo Bontempelli usou a expressão realismo mágico para caracterizar algumas manifestações das artes plásti- 
cas que suplantavam o futurismo e apresentavam elementos que faziam emergir o insólito do prosaico.

Na América Latina, foi o venezuelano Arturo Uslar Pietri, em 1948, o primeiro a usar o termo realismo mágico dirigido à arte literária. Pietri, segundo Chiampi, percebe no termo uma ambiguidade insolúvel: "o poético consiste em buscar realisticamente o mistério além das aparências (adivinhar) ou o poético consiste em praticar o irrealismo (negar a realidade)" (CHIAMPI, 1980, p. 23). Angel Fores, numa conferência em 1954, afirma que o realismo mágico teria criado solo em terras latino-americanas, em 1935, com Jorge Luís Borges e sua História universal da infâmia, dada a naturalização do irreal existente nessa obra. Luís Leal, em 1967, nega a naturalização do irreal para definir o realismo mágico e defende que nas obras latinoamericanas aflora uma sobrenaturalização do real e, nesse ponto, ele anuncia, de maneira modesta, a proposta de real maravilhoso, que será implantada pelo escritor Alejo Carpentier.

Em 1948, o escritor cubano Alejo Carpentier tece suas primeiras considerações sobre a tendência literária que será por ele designada como real maravilhoso no prólogo de $O$ reino deste mundo. Esse romance traz aos leitores a história da revolta dos escravos no Haiti ocorrida no final do século XVIII e toma como perspectiva para a narração o olhar do escravo Ti Noel. Na epígrafe do prólogo desse romance, Carpentier já faz menção ao poder de Mackandal e de Ti Noel de metamorfosearem-se em animais. Esses fatos e outros, tão insólitos se considerados pela ótica da lógica, sal-tam aos olhos do leitor como fatos sólitos para a cultura em que eles ir-rompem. Carpentier relata que, na sua visita ao Haiti, percebeu que o real maravilhoso estava entranhado por todo lugar onde passava e deduz que essa presença do real maravilhoso não seria exclusiva ao Haiti, mas "patri- mônio da América inteira" (CARPENTIER, 2009, p. 10). Ele alega que essa natureza maravilhosa americana encontra-se vinculada a uma percepção e experiência maravilhosas da realidade. Nesse prólogo, Carpentier irá con- trapor o real maravilhoso às técnicas surrealistas. Vale lembrar que Alejo Carpentier, juntamente com Uslar Pietri, havia participado das reuniões do grupo de artistas surrealistas em Paris.

O autor cubano, que tinha rompido com o grupo surrealista de André Breton, estabelece um paralelo entre Mackandal (personagem histórico) e Maldoror (personagem fictício) da obra Les chants de Maldoror, de Isadore Ducasse, Comte de Lautréamont. Ambos os personagens têm poderes licantrópicos, ou seja, a capacidade de se transformar em diferentes animais, desaparecendo subitamente e reaparecendo em outros lugares, sob outras 
formas. Entretanto, o que era fiç̧ão na Europa torna-se realidade na América (ESTEVES; FIGUEIREDO, 2010, p. 408).

Acrescento que a obra de Carpentier certamente é também uma ficção e sua personagem Mackandal, mesmo tendo um modelo fortemente retirado da realidade haitiana, é igualmente ficcional. $\mathrm{O}$ que é ressaltado por Carpentier é o fato de Maldoror não ter uma existência concreta na cultura europeia e Mackhandal, bem como todas as personagens com características licantrópicas e relacionadas ao vodu de $O$ reino deste mundo, terem efetivamente uma existência na cultura de Haiti.

Carpentier enfatiza que o maravilhoso dos surrealistas é "obtido com truques de prestidigitação, reunindo-se objetos que não se costumam juntar: a velha máquina de costura sobre uma mesa de dissecação [...], os caracóis no táxi chuvoso, a cabeça de leão na pélvis de uma viúva" (CARPENTIER, 2009, p. 7).

Seguindo o olhar de Carpentier, entendo que o real maravilhoso é aquele tipo de insólito que se encontra entranhado na cultura de um povo e que às vezes migra desse lugar para as páginas de um livro. Como nos ensina Carpentier:

o maravilhoso começa a sê-lo de maneira inequívoca quando surge de uma alteração da realidade (o milagre), de uma revelação privilegiada da realidade, de uma iluminação inabitual ou especialmente favorecedora das inadvertidas riquezas da realidade, percebidas com particular intensidade em virtude de uma exaltação de espírito que conduz a um modo de "estado limite". Para começar, a sensação de maravilhoso pressupõe uma fé. Os que não acreditam com milagres de santos não podem curar-se com milagres de santos (CARPENTIER, 2009, p. 9).

A citação extensa foi necessária porque nela se concentra o fundamento central da noção de real maravilhoso apresentada por Carpentier em contraposição a tendências como a do surrealismo e do realismo mági- co. $\mathrm{E}$ também é com base nela que realizaremos a leitura de "Um senhor muito velho com umas asas enormes" e de "Um moço muito branco", dois contos latino-americanos em que o sentido de uma realidade maravilhosa é que vai propiciar o desenrolar dos fatos.

Em 1964, Carpentier escreve "Do real maravilhoso americano" (1987), texto em que ele retomará ipsis litteris o texto do prólogo de $O$ rei- no deste mundo, mas que, nas primeiras páginas introduz novas formas de perceber o real maravilhoso em outras partes do mundo, não só na Améri- ca. Em sua visita pela China, por exemplo, Carpentier estarrece-se com as 
coisas interessantíssimas que viu e admite que não as compreendeu e que para isso teria que entender melhor a língua e a cultura daquele povo. Assim, essas maravilhas chinesas, tais quais as da América, encontram-se entranhadas à cultura do povo. Em 22 de maio de 1975, Carpentier profere uma conferência intitulada "O barroco e o real maravilhoso" no Ateneu de Caracas, na qual ele retoma a noção de real maravilhoso associando-a à de barroco. Mais do que um simples e datado estilo de época, no ver do escritor cubano, o barroco é "uma espécie de força criadora que retorna ciclicamente ao longo de toda a história das manifestações artísticas" (CARPENTIER, 1987, p. 111). O barroco, para ele, caracteriza-se pelo horror ao vazio, pela aversão à harmonia; é uma arte que pulsa e é capaz de arrombar os seus próprios limites. E por que a associação do real maravilhoso e da América com o barroco? "Porque toda simbiose, toda mestiçagem, engendra um barroquismo" (CARPENTIER, 1987, p. 121). Ambos, o barroco e o real maravilhoso, pela argumentação feita por Carpentier, seriam impregnados pelo maravilhoso e este tem relação direta com o extraordinário e o assombroso: "O extraordinário não é necessariamente belo ou bonito. Não é bonito nem feio; é acima de tudo assombroso por aquilo que tem de insólito. Tudo o que é insólito, tudo o que é assombroso, tudo o que escapa a normas estabelecidas é maravilhoso" (CARPENTIER, 1987, p. 122). Nessa conferência, ainda, ele retoma a diferença entre o surrealismo e o real maravilhoso, bem como insere a diferença entre o real maravilhoso e o realismo mágico. Carpentier resgata Franz Roh e ressalta que o realismo mágico é a arte que combina formas reais de um modo não condizente com a realidade cotidiana. E por isso essas formas divergem do real maravilhoso, já que este é "aquele que encontramos em estado bruto, latente, onipresente em tudo o que é latino-americano", visto que em terras latino-americanas o cotidiano é naturalmente insólito (CARPENTIER, 1987, p. 125).

Com o real maravilhoso percebo que não se trata de o poético praticar o irrealismo, negando o real (como entendia Pietri em relação ao realismo mágico), porque a própria realidade latino-americana encontra-se conjugada a uma irrealidade, ela é maravilhosa. Este é, em meu ponto de vista, a grande diferença entre o modo do realismo mágico e o do real maravilhoso.

Cabe comentar acerca do realismo maravilhoso, noção discutida por Irlemar Chiampi e vinculada à de real maravilhoso. Chiampi opta por maravilhoso em vez de mágico, porque o termo maravilhoso encontra-se já vinculado aos estudos literários, o mágico, por outro lado, encontra-se relacio- 
nado a outras áreas e séries culturais. Ela explica ainda que o maravilhoso é aquilo que contém a maravilha, mirabilia, que se contrapõe àquilo que é da ordem dos naturalia, ou realia. Mirabilia, por sua vez, contém o mirar, ver através de; ou ainda: mirar relaciona-se à miragem, milagre. A eleição pelo termo realismo em vez de real, ela explica da seguinte forma:

a opção por definir o realismo maravilhoso pela combinação dos termos contraditórios visou acolher no seu bojo uma contrariedade inicial, se lembrarmos que os termos contêm as relações de implicação com os termos contraditórios contêm as relações de implicação com os termos contrários (Sं2-----S1) e (S่1-----S2). Com a formulação adotada preserva-se, ainda, a oposição entre o discurso realista maravilhoso e os discursos realista e maravilhoso, além de marcar-se a vizinhança formal daquele código realista $(\mathrm{S} 1+\dot{\mathrm{S}} 1)$ e a outra o código do maravilhoso (S2 + Sं2) (CHIAMPI, 1980, p. 145).

Como procurei demonstrar, ainda que em muitos estudos procurem tecer uma equivalência dos termos realismo mágico e real maravilhoso, essas noções apontam para direções distintas de trabalho com o insólito e isso faz com que eles manifestem-se como dois diferentes modos de fantás- tico. Já a noção de realismo maravilhoso estudada por Chiampi aproxima-se muito da noção de real maravilhoso de Alejo Carpentier. Eu prefiro adotar o termo cunhado por Carpentier por entender que a relação de contraditori- edade também se estabelece de forma exemplar entre real e maravilhoso e não só entre realismo e maravilhoso. Na análise que segue, mostrarei como os contos de Gabriel García Márquez e de João Guimarães Rosa podem ser lidos de forma plena pelas considerações ensaísticas de Carpentier sobre o maravilhoso em terras da América.

\section{ESPAÇOS DOS MIRABILIA E ANJOS PERDIDOS}

Pelos vilarejos do interior do Brasil e dos outros países da América do Sul e Central é muito comum escutarmos "causos" que relatam histórias de pessoas com dons, crianças santinhas e aparições de anjos. Em todas as histórias o encantamento mescla-se a uma crença que desencadeia toda força da narrativa. E em quase todas elas, há a presença de algum morador da cidadezinha que viveu ou testemunhou o acontecimento insólito, acontecimento esse que, apesar de maravilhoso, é comum para as pessoas daquele lugar.

Nos dois contos que tomo para análise um elemento insólito é comum: a aparição de um anjo. Essa aparição ocorre, nesses contos, acompa- 
nhada por desastres naturais provocados por chuvas torrenciais. Em "Um senhor muito velho com umas asas enormes", de Gabriel García Márquez, o anjo surge após o terceiro dia de chuva, a qual havia deixado o lugarejo inundado, com caranguejos invadindo a casa de Pelayo, "céu e mar eram uma só coisa cinza" (MÁRQUEZ, s. d., p. 9), as areias da praia eram puro lodo e lamaçal. Em "Um moço muito branco", tudo ocorre igualmente após um "fenômeno luminoso" surgir no céu e cair um "medonho temporal" (ROSA, 1972, p. 99); sucedeu uma vasta inundação, e uma revolução total na natureza, uma vez que morros sumiram, riachos foram deslocados de seus lugares, criaturas e criações foram soterradas, afogadas, sofreram. Assim, nos dois casos, uma calamidade provocada pelas forças da natureza é que colocará os anjos entre os seres humanos. Há nessa associação calamidade/aparição do anjo uma lógica, visto que essa calamidade está relacionada às chuvas e estas advêm dos céus, locus imaginário onde habitam os seres celestes, como os anjos.

A aparição do anjo em "Um senhor muito velho com umas asas enormes" causou um "calado estupor" em Pelayo e em sua esposa, Elisenda; e o narrador, que narra com uma focalização em terceira pessoa, assim o descreve: "Estava vestido como um trapeiro. Restavam-lhe apenas uns fiapos descorados na cabeça pelada e muito poucos dentes na boca, e sua lastimável condição de bisavô ensopado o havia desprovido de toda grandeza. Suas asas de grande galináceo, sujas e meio depenadas, estavam encalhadas para sempre no lodaçal" (MÁRQUEZ, s.d., p. 99). Há um destronamento da imagem usual do anjo, pois este não é jovem e belo, mas muito velho, com aparência não de avô, mas de bisavô, com asas comparadas às de um galináceo, enlameadas, sujas. Suas poucas penas quase o fazem um desasado. Pelayo e Elisenda assombram-se no início, mas depois acabam achando o anjo um ser familiar. Quem vai dizer aos dois que de fato trata- se de um ajo é uma vizinha sabedora de todas as coisas da vida e da morte. Para ela, era um anjo que havia vindo buscar o filho adoentado de Pelayo e Elisenda, mas não tinha conseguido porque a chuva o derrubara antes. O ser surge, então com um anjo da morte. Na tradição judaica, o anjo da mor- te é nomeado Samael, aquele que desposou Lilith após ela ter repudiado Adão. Na Bíblia, no Livro do Apocalipse, esse ser da morte é nomeado como "Anjo do Abismo", Abadon em hebraico e Apolíon, em grego. Porém no conto de Gabriel García Márquez ele é inominado, sequer descrito direta- mente como anjo da morte, contudo, pela sua associação com a iminência da morte do menino e pela descrição grotesca, disfórica, o leitor é levado 
possivelmente a considerá-lo dessa forma. Para a vizinha sapiente, "os anjos destes tempos eram sobreviventes fugitivos de uma conspiração celestial" (MÁRQUEZ, s.d., p. 10), contudo, Pelayo e Elisenda, bem como os demais moradores do lugarejo, não tiveram coragem de enxotá-lo ou matá-lo. Logo após a chegada do anjo, a chuva cessa e o menino, filho de Pelayo e Elisenda, recupera-se da doença, o que faz com que todos acolham de certa forma aquele ser tão estranho. Após a quebra do assombro e a consequente familiarização do estranho, o anjo velho passa a viver no galinheiro e torna-se atração para os curiosos e necessitados de milagres. Quando o dia amanheceu, "encontraram toda a vizinhança diante do galinheiro, brincando com o anjo sem a menor devoção e atirando-lhe coisas para comer pelos buracos alambrados, como se não fosse uma criatura sobrenatural mas um animal de circo" (MÁRQUEZ, s.d., p. 10).

Porém, é preciso perceber se ocorre uma naturalização do irreal é porque ocorreu - e de forma muito mais intensa - anteriormente a sobrenaturalização do real. Por isso, temos o caso do real maravilhoso. Esse real admite anjos que caem do céu e ficam impossibilitados por um tempo de alçar voos.

A mesma sobrenaturalização do real ocorre relacionada à aparição do anjo em "Um moço muito branco":

era um moço de distintas formas, mas em lástima de condições, sem o restante de trapos com que se compor, pelo que enrolado em pano, espécie de manta de cobrir cavalos, achada não se supõe onde; e, assim em acanho, foi ele avistado, de muito manhã, aparecendo e se escondendo por detrás do cercado de vacas (ROSA, 1972, p. 99).

E, depois, ocorrerá uma naturalização daquilo que é estranho.

Há similaridades evidentes entre os dois anjos latino-americanos, como a imagem dos trapos como vestimentas dos anjos e sua inserção no espaço dos animais: o de Márquez em meio a um galinheiro e o de Rosa situado perto das vacas.

Essa sobrenaturalização do real é configurada em função de culturas, como fica bem demonstrado ao longo das duas narrativas, culturas essas que se predispõem a crer que o cotidiano é tecido não só pelo real, mas também por insólitos acontecimentos. Como afirma Carpentier (1987, p. 125), "aqui [na cultura latino-americana] o insólito é cotidiano, sempre foi cotidiano."

A comparação do moço muito branco com o ser-anjo é dada por meio do relato do escravo "meio alforriado" José Kakende e a visão que 
teve da chegada daquele ser: "o rojo de vento e grandeza de nuvem, em resplandor, e nela, entre fogo, se movendo uma artimanha amarelo-escura, avoante trem, chato e redondo, com redoma de vidro sobreposta, azulosa, e que, pousando, de dentro, desceram os Arcanjos, mediante rodas, labare-das e rumores" (ROSA, 1972, p. 101, grifos do autor citado). Nesse caso, a chegada do anjo acontece por meio de um grande objeto que se assemelha ao formato tão popularmente descrito como o das naves espaciais, portadoras dos seres extraterrestres. A associação dos seres angelicais com os extraterrestres deve-se certamente ao fato de ambos virem dos céus e representarem o enigmático, o ser que, pelo seu mistério, situa-se na linha tênue entre o real e o irreal.

Enquanto o anjo de Márquez é representado por intermédio de uma caracterização disfórica, com formas decrépitas, o de Rosa é todo representado por tons e traços eufóricos, positivos. $O$ anjo de Rosa não tem asas a princípio (só as terá ao final), mas é qualificado esteticamente de forma a ressaltar em sua aparência a luminosidade: "Tão branco; mas não branquicelo, senão que de um branco leve, semidourado de luz: figurando ter por dentro da pele uma segunda claridade. Sobremodo se assemelhava a esses estrangeiros que a gente não depara que nunca viu; fazia para si uma outra raça" (ROSA, 1972, p. 99). Já o anjo de Márquez é pintado por uma representação envolta por lama e lodo, ou seja, há nele uma ausência de luz. Somente ao final da narrativa, quando chega a época dos primeiros sóis, após uma invernada que deixava céu e mar acinzentados, o anjo velho do conto de Márquez começa a renascer. É de notar que o anjo de Rosa carre- ga em si, na sua pele e por debaixo dela, a luz, talvez pela sua juventude, afinal, o anjo é um moço muito branco; em contraponto, o anjo de Már- quez, possivelmente por ser um senhor muito velho, já não tem a sua luz interna e necessita da luminosidade externa para poder ter novas forças e conseguir voar novamente, o que ocorre no final. Tanto o anjo de Rosa como o de Márquez, guardadas as devidas diferenças entre euforia e disfo- ria, então, têm uma relação forte com a luz.

Gustav Fechner, um dos fundadores da Psicologia moderna, em Da anatomia comparada dos anjos, afirma que a luz é o elemento dos anjos, assim como o ar é o nosso, e toda a natureza dos seres angelicais está ligada à luminosidade. Como explica Fechner, "os anjos são em si translúcidos, mas dispõem de toda a amplitude para se darem cores" (1998, p. 39). A relação do anjo com a luminosidade é mais trabalhada no conto de Rosa, pois ao longo de toda a narrativa temos não só a sua caracterização como 
também os acontecimentos que ocorrem em seu entorno vinculados ao elemento ígneo. O fogo parece compor o seu ser e por isso, antes de desaparecer do lugarejo, acende nove fogueiras, número não ao acaso, porque os anjos "são hierarquizados em nove coros, ou três tríades: a perfeição da perfeição, a ordem na ordem, a unidade na unidade" (CHEVALIER; GHEERBRANT, 1990, p. 642). Ao tratar da psicanálise do fogo, Gaston Bachelard explica que o fogo é o elemento que mais sugere o desejo de mudança, de "apressar o tempo, de levar a vida a seu termo, a seu além" (BACHELARD, 1999, p. 25) e a fogueira do fogo não deve ser entendida como mera destruição, mas símbolo potente de renovação. Por isso o fogo é portador de morte e de vida.

$O$ anjo que surge na casa de Pelayo e Elisenda, como demonstrei, tem sua relação com a luz, mas esta só se anuncia quando ele se recupera e consegue alçar voo. A água parece ser o elemento que mais define a natureza do anjo de Márquez, uma vez que ele surge próximo ao mar e é comparado a um marinheiro por mais de uma vez pelo narrador. Com muito cuidado para que os outros não o ouvissem, cantava canções de marinheiro sob as estrelas. No final, o quadro pintado pelo seu voo, traz o mar, as águas, como cenário de revitalização. O narrador conta que quem presen- ciou o voo do anjo foi Elisenda. Da cozinha, "continuou vendo-o até acabar de cortar a cebola, e até quando já não era mais possível que o pudesse ver, porque então não era mais um estorvo em sua vida, mas um ponto imaginário no horizonte do mar" (MÁRQUEZ, s.d., p. 18). Essa relação do anjo com as águas parece ser muito inusitada, mas a água, assim como o fogo, é portadora de vida e de morte. Entretanto, ainda que tenha uma relação com a vida, a água, para Bachelard (1997), é a própria morte. O Complexo de Caronte e o de Ofélia são analisados por Bachelard em toda sua afinida- de com as águas que são portadoras de morte. Talvez por isso, no conto do autor colombiano, o anjo, como já afirmei, parece vir representado como um anjo da morte.

Outro aspecto que une as duas narrativas é a linguagem dos anjos neles representados. No conto de Márquez, Pelayo e Elisenda tentam falar com o anjo, porém "ele lhes respondeu em um dialeto incompreensível mas com uma boa voz de marinheiro" (MÁRQUEZ, s. d., p. 9) e quando o Padre Gonzaga tenta comunicar-se com ele em Latim, não obtém resultado. Para o padre isso já era uma forte prova de que aquele ser, por não enten- der a "língua de Deus", seria um impostor. O leitor logo percebe a ironia de Márquez em relação aos dogmas cristãos. O anjo de Rosa, que aparece no 
interior de Minas Gerais, na cidadezinha de Serro Frio, na noite de onze de novembro de 1872, parecia ter perdido a memória e não se expressava por fala: "Nada ouvindo, não respondia, nem que não, nem que sim; o que era coisa de compaixão e lamentosa. Nem fizesse entender, isto é, entendia, às vezes ao contrário, os gestos" (ROSA, 1972, p. 100). Portanto, uma outra similaridade entre os dois anjos e que aponta para a representação de ambos como um ser estrangeiro e estranho é certa incomunicabilidade. Se comparados os dois, esse aspecto é mais forte no anjo de Márquez do que no de Rosa; enquanto o primeiro fica praticamente isolado toda a narrativa, até mesmo nos momentos em que são feitas aglomerações para vê-lo, o segundo, apesar de suas marcadas e acentuadas diferenças, inclusive a linguística, integra-se à comunidade, é cobiçado pelo fazendeiro Duarte Dias.

É preciso relatar um pouco mais o fio em que se enreda as histórias para que fique mais evidente essa diferença. $O$ anjo de Márquez, um homem muito velho com umas asas enormes, é descoberto por Pelayo e Elisenda e depois disso, como um milagre, o filho dos dois restabelece-se da doença que o afligia. Num misto de curiosidade e de busca por possíveis outros milagres a população cerca o galinheiro, morada provisória do anjo velho. Várias conjeturas são criadas sobre o estranho cativo, uns achavam que ele deveria ser o prefeito do mundo, outros que ele deveria ser promovido a general, outros acreditavam que ele precisaria ser transformado em reprodutor para dar origem a uma nova raça de homens alados e sapientes. O Padre Gonzaga, atraído pela exageração do fato, tenta um diálogo com o anjo, diálogo esse que não se concretiza, e, como consequência, adverte a população sobre o perigo que ali se estabelecia, pois "o demônio tinha o mau costume de recorrer a artifícios para confundir os incautos" (MÁRQUEZ, s. d., p. 12). Resolve que vai "escrever uma carta a seu bispo, para que este escrevesse outra a seu primaz e para que este escrevesse outra ao Sumo Pontífice, de modo que o veredicto final viesse dos tribunais mais altos" (MÁRQUEZ, s. d., p. 12). Essa rede alongada de cartas represen- ta ironicamente a atitude da Igreja perante a crença dos homens, pois a palavra da Igreja tem que ser a mais poderosa e aquela que deve nortear o certo e o errado em relação aos padrões sociais e as crenças que devem ser cultuadas. Mas a Igreja, como diz ironicamente o narrador, "perdera a no- ção de urgência" (MÁRQUEZ, s. d., p. 14), pois fizera mais conjeturas do que a população, inclusive a de que o homem muito velho poderia ser apenas um norueguês com asas enormes. Aqui fica intensa mais uma vez a relação 
do ser alado com a noção de estrangeiro. Segundo Julia Kristeva (1994, p. 9), "o estrangeiro começa quando surge a consciência de minha diferença e termina quando nos reconhecemos todos estrangeiros, rebeldes aos vínculos e às comunidades." No caso da narrativa de Márquez, a rebeldia não acontece e o infeliz anjo velho passa toda a narrativa na condição de estrangeiro e excluído. Há no conto uma crítica intensa em relação à imposição de poder da Igreja e vale recordar que a colonização da América foi efetuada com base numa colonização religiosa. Os padres e demais religiosos europeus subjugaram os povos com a sua cultura e a sua língua, tentando ensinar o Latim inclusive aos índios, os quais, como o anjo velho de Márquez, falavam uma língua incompreensível.

A população ia ao anjo velho como quem ia à procura de uma aberração circense, até que um dia uma das pessoas que vai visitá-lo foi uma mulher que havia se transformado em aranha por haver desobedecido aos seus pais. Aliás, essa aranha-mulher, com corpo de uma tarântula enorme e cabeça de donzela, é uma figura recorrente em outras narrativas do autor colombiano. $O$ espetáculo da aranha-mulher acaba suplantando o espetáculo do anjo velho caído e cativo no galinheiro. Ela era mais acessível à curiosidade do povo, respondia as perguntas a ela dirigidas, ao passo que o anjo velho e cativo quedava apenas em um canto do galinheiro, taciturno. E os escassos milagres do anjo não o ajudavam muito, porque eram "milagres de consolação": um cego, em vez de recuperar sua visão, ganhou três den- tes novos; um paralítico não voltou a andar, mas ganhou na loteria; as feri- das de um leproso não curaram, porém delas brotaram girassóis. Todo esse contexto levou as pessoas a abandonarem o anjo solitário em seu galinheiro. Pelayo e Elisenda, com o dinheiro que arrecadaram do povo pelas visitas ao anjo cativo, construíram uma mansão e deixaram o anjo velho no enveIhecido galinheiro, isolado, com sua estranha sina de ter caído do céu e/ou vindo do mar. Quando o galinheiro é destruído com o passar dos tempos e das intempéries climáticas, Pelayo joga sobre o anjo uma manta e faz a caridade de ceder-Ihe o alpendre como provisória morada. Ele às vezes surpreendia Elisenda, aparecendo aqui e ali, nos quartos, na cozinha, como se fosse capaz de ocupar vários lugares ao mesmo tempo. Eis que um dia, como já relatei, com a chegada dos primeiros sóis, e após vários dias de imobilidade, o anjo começa a ensaiar tentativas de voo até que consegue sair do seu cativeiro. É evidente, pois, o estado de reclusão do anjo em vir-tude da incompreensão do homem pelo diferente. Kristeva assinala o vagar constante do estrangeiro provocado pela rejeição, uma ferida constante: "A

132 Número temático: Vertentes do insólito nas literaturas das Américas. A Cor das Letras UEFS, n. 15, 2014 
rejeição de um lado, o inacessível do outro: se tiver forças para não sucumbir a isso, resta procurar um caminho" (KRISTEVA, 1994, p. 13). É o que faz o anjo velho do conto de Márquez, pois alça voo à procura de um outro lugar para cair/surgir.

A trajetória do moço muito branco que surge na comarca de Serro Frio é diferente, uma vez que logo após a sua aparição na Fazenda do Cas- co, no dia de São Félix, Hilário Cordeiro, o dono da fazenda o acolhe, dando- Ihe teto, roupa, comida e, pelo que a narrativa sugere, carinho. O nome do sujeito que acolhe o anjo dá mostras de sua caracterização simbólica, pois hilário é aquele que atrai para si risos (por ser diferente também?), e cordeiro é o cordato, o pacífico. Como o anjo de Márquez, o moço muito branco atraiu a população pelas suas inusitadas aparência e aparição. O moço foi levado à missa, porém "não fez modos de crer nem increr" (ROSA, 1972, p. 101) no ritual desconhecido para ele. Para o bondoso Padre Bayão: "Comparados com ele, nós todos, comuns, temos os semblantes duros e o aspecto de má fadiga constante" (ROSA, 1972, p. 101, grifos do autor citado). A comparação eleva o ser diferente em relação aos demais, não o rebaixa. "Os amigos do estrangeiro", explica Kristeva (1994, p. 31), "somente poderiam ser aqueles que se sentem estrangeiros de si mesmos." No caso da narrativa de Rosa, diferentemente da de Márquez, há a rebeldia em relação ao conviver com o outro, que é estrangeiro, e com o estrangeiro que habita em nós. Todos na narrativa parecem reconhecer em si uma par-cela de estrangeiro. Além de Hilário Cordeiro, o moço muito branco atrai a simpatia do negro José Kakende, que, por ser um escravo "meio alforriado" abarca em si a condição de estrangeiro. Viviana, filha de Duarte Dias, que era triste por natureza, enternece-se pelo anjo-moço.

Os milagres do moço muito branco não eram de consolação como os do homem muito velho com asas enormes, eram milagres que traziam coisas diferentes e boas. Por isso ele foi cobiçado pelo maligno e injusto Duarte Dias, pai da bela Viviana. Duarte Dias queria ter em sua posse o moço, mas este parecia mostrar com seus atos que o cativeiro não seria a sua morada. O nome Duarte indica o desejo de posse da personagem: aquele que guarda, o guardião.

O anjo muito branco dá ao cego Nicolau uma semente e desta brotará um pé de flores azuladas jamais vistas, flores inesperadas. Na vida de Hilário Cordeiro tudo passou a ser repleto de saúde e de paz. Depois de colocar a mão no seio da bela mais infeliz Viviana, desperta nela "um enfim de alegria" (ROSA, 1972, p. 103). Após as súplicas e até lágrimas de Duarte 

rejeição de um lado, o inacessível do outro: se tiver forças para não sucumbir a isso, resta procurar um caminho" (KRISTEVA, 1994, p. 13). É o que faz o anjo velho do conto de Márquez, pois alça voo à procura de um outro lugar para cair/surgir.

A trajetória do moço muito branco que surge na comarca de Serro Frio é diferente, uma vez que logo após a sua aparição na Fazenda do Cas- co, no dia de São Félix, Hilário Cordeiro, o dono da fazenda o acolhe, dando- Ihe teto, roupa, comida e, pelo que a narrativa sugere, carinho. O nome do sujeito que acolhe o anjo dá mostras de sua caracterização simbólica, pois hilário é aquele que atrai para si risos (por ser diferente também?), e cordeiro é o cordato, o pacífico. Como o anjo de Márquez, o moço muito branco atraiu a população pelas suas inusitadas aparência e aparição. $O$ moço foi levado à missa, porém "não fez modos de crer nem increr" (ROSA, 1972, p. 101) no ritual desconhecido para ele. Para o bondoso Padre Bayão: "Comparados com ele, nós todos, comuns, temos os semblantes duros e o aspecto de má fadiga constante" (ROSA, 1972, p. 101, grifos do autor citado). A comparação eleva o ser diferente em relação aos demais, não o rebaixa. "Os amigos do estrangeiro", explica Kristeva (1994, p. 31), "somente poderiam ser aqueles que se sentem estrangeiros de si mesmos." No caso da narrativa de Rosa, diferentemente da de Márquez, há a rebeldia em relação ao conviver com o outro, que é estrangeiro, e com o estrangeiro que habita em nós. Todos na narrativa parecem reconhecer em si uma par-cela de estrangeiro. Além de Hilário Cordeiro, o moço muito branco atrai a simpatia do negro José Kakende, que, por ser um escravo "meio alforriado" abarca em si a condição de estrangeiro. Viviana, filha de Duarte Dias, que era triste por natureza, enternece-se pelo anjo-moço.

Os milagres do moço muito branco não eram de consolação como os do homem muito velho com asas enormes, eram milagres que traziam coisas diferentes e boas. Por isso ele foi cobiçado pelo maligno e injusto Duarte Dias, pai da bela Viviana. Duarte Dias queria ter em sua posse o moço, mas este parecia mostrar com seus atos que o cativeiro não seria a sua morada. O nome Duarte indica o desejo de posse da personagem: aquele que guarda, o guardião.

O anjo muito branco dá ao cego Nicolau uma semente e desta brotará um pé de flores azuladas jamais vistas, flores inesperadas. Na vida de Hilário Cordeiro tudo passou a ser repleto de saúde e de paz. Depois de colocar a mão no seio da bela mais infeliz Viviana, desperta nela "um enfim de alegria" (ROSA, 1972, p. 103). Após as súplicas e até lágrimas de Duarte 
Dias, o moço não se entrega a ele, mas indica um lugar e pede que ele cave; lá havia "uma grupiara de diamantes; ou um panelão de dinheiro, segundo diversa tradição" (ROSA, 1972, p. 104).

Depois de acender nove fogueiras com a ajuda do amigo Kakende, "o moço se fora, tidas asas" (ROSA, 1972, p. 104). Por meio da poeticidade da linguagem de Guimarães Rosa, as asas do anjo, que não se fizeram presentes ao longo da narrativa, surgem ao final como forma de alçá-lo a um outro lugar. Sobre a relação dos anjos não com a Terra, mas com o universo, Fechner argumenta: "o homem possui apenas uma fraca correspondência na sensação que lhe indica a posição de seu centro de gravidade em relação à Terra, e que lhe está presente tanto em repouso quanto em movimento. Já os anjos têm a sensação correspondente em sua relação com o universo inteiro" (FECHNER, 1998, p. 65). Por isso eles não se prendem a lugar al-gum, são seres que transitam; é o que ocorre com os dois anjos dos contos.

Um tema recorrente em narrativas fantásticas, de acordo com Remo Ceserani (2006) é a passagem de limite e de fronteira, por isso é comum habitarem essas narrativas seres que se encontram em uma zona de indiscernibilidade. Essa zona pode ser compreendida como espaços marginais, como o espaço dos anjos de Márquez e de Rosa, que é definido pela diferença, pela indefinição.

A indefinição marca não só o espaço geográfico e social dos anjos, ela é registrada desde o título das narrativas. Não se trata de "o" moço, mas de "um" moço; nem de "o" senhor muito velho, mas de "um" senhor muito velho. E esse ser velhíssimo não tem "as" asas, mas "umas" asas. Os artigos indefinidos dos títulos já anunciam, nesse caso, o lugar de indiscernibilidade das personagens. Nos títulos, outra similaridade é notável: o da exageração das características desses seres indiscerníveis: "Um senhor muito velho com umas asas enormes" e "Um moço muito branco" (grifos meus). Tem-se, nos dois casos, uma adjetivação que se desvela superlativa, destacando as personagens por meio de uma marca de superioridade. $O$ velho não é apenas velho, mas muito velho e suas asas não são grandes, porém enormes. O moço não é branco apenas, todavia muito branco. Esse exagero possibilita o leitor a entrar preparado em narrativas que vão delinear histórias de se- res diferentes por sua caracterização e por suas ações. De acordo com To- dorov (2004, p. 86), "[o] exagero conduz ao sobrenatural”. A representação hiperbólica da caracterização dos corpos (muito velho, com asas enormes, muito branco) conferirá mais falta de solidez ainda a esses seres anjos, personagens nada comuns ao mundo dos terrestres humanos.

134 Número temático: Vertentes do insólito nas literaturas das Américas. A Cor das Letras UEFS, n. 15, 2014 


\section{ENTRETECENDO OS FIOS DOS CONTOS: O REAL MARAVILHOSO}

Em seu estudo intitulado "Uma metáfora da realidade", a estudiosa Bella Josef faz uma leitura atenta do romance Cem anos de solidão, do colombiano Gabriel García Márquez. A análise atrai a atenção do leitor para as técnicas usadas pelo autor no sentido de fazer irromper o sobrenatural em meio a uma realidade cotidiana. Porém discordo da autora no momento em que, para explicar o modo fantástico utilizado por Márquez, ela afirma que "é uma nova dimensão da realidade, que tem antecedentes no realismo mágico de Alejo Carpentier" (JOSEF, 1993, p. 175). A autora, conforme se pode verificar, toma como sinônimas as noções de real maravilhoso e de realismo mágico. Como demonstrei anteriormente, o próprio Carpentier ressalta a diferença entre essas noções. E, concordando com Carpentier, defendo que essas noções se tratam de dois modos diversos de trabalho com a literatura que tem o insólito como base de criação.

No realismo mágico, como explica Alejo Carpentier, o elemento/acontecimento é fabricado pelo autor sem haver uma vinculação com alguma determinada realidade maravilhosa colhida por ele no seio de uma cultura. No real maravilhoso acontece exatamente o oposto, pois o insólito ficcionalizado pelo autor já existe de forma "latente e onipresente" (CARPENTIER, 1987, p. 125) em sua realidade cultural. Por esse motivo, acredita Carpentier, o real maravilhoso vincula-se a uma questão de fé. Essa fé não se relaciona necessariamente a uma fé religiosa, entretanto a uma crença que define a modo cultural de um povo viver e agir. Isso não quer dizer que, em muitos casos, essa fé esteja vinculada de certa forma a pensares religiosos, como é o caso dos dois contos em tela neste artigo. No conto de Rosa, por exemplo, não é por acaso que a trajetória do moço mui- to branco parece ser demarcada por dias religiosos: ele é encontrado no dia de São Félix; uma das tentativas de Duarte Dias tomar posse do moço e levá-lo à sua fazenda acontece no dia de Nossa Senhora das Neves; e sua ida, seu "desaparecer", ocorre no dia de Santa Brígida. No conto de Már- quez, é posta em relevo a ideia bíblica do anjo caído como um ser possi- velmente amaldiçoado.

Nos dois contos, aquilo que é da ordem do sobrenatural irrompe com toda a potência da sobrenaturalidade, todavia esta não entra em choque com o mundo prosaico, tão comum mas tão ambíguo também. Os anjos não deixam de serem criaturas diferentes, daí o caráter estrangeiro a eles 
conferido no decorrer das narrativas. As personagens, no entanto, creem na existência deles, porque é natural na sua cultura. Anjos e demônios encarnados são seres cuja existência é narrada em muitos causos e histórias dos interiores das Américas.

Há, no trabalho com o real maravilhoso, uma estética que joga com o paradoxo entre aquilo que é oculto e ao mesmo tempo familiar. Freud (2010), ao estudar o inquietante, parte da análise verticalizada sobre o termo heimlich e conclui que essa palavra, entre as suas várias possibilidades de significado, ostenta também uma que converge com o seu oposto, $u$ nheimlich. O que é heimlich vem a ser unheimlich. O termo heimlich, então, reporta-se a dois grupos de conceitos que, não sendo opostos, são estranhos um ao outro: o do que é familiar, aconchegado / o do que é escondido, mantido oculto. E, resgatando Shelling, Freud conclui que unheimlich seria tudo o que deveria permanecer secreto, oculto, mas apareceu. Heimlich engendra o seu significado na direção da ambiguidade, até afinal coincidir com o seu oposto. E por essa razão unheimlich é de certo modo heimlich. Nesse sentido, compreendo que o termo inquietante abre-se como uma pertinente possibilidade para o estudo do real maravilhoso. Os anjos decaídos das duas histórias inquietam pela insólita manifestação de seres que existem de forma oculta, porém que, em um momento, irrompem, aparecem não sub-repticiamente, mas desvelando suas diferenças positivas ou negativas em comparação com os outros seres, estranhos a eles.

O que é, então, a história da América senão uma crônica do inquietante real maravilhoso?

\section{REFERÊNCIAS}

BACHELARD, Gaston. A água e os sonhos: ensaio sobre a imaginação da matéria. Trad. Antonio de Pádua Danesi. São Paulo: Martins Fontes, 1997.

BACHELARD, Gaston. A psicanálise do fogo. Trad. Paulo Neves. São Paulo: Martins Fontes, 1999.

BESSIÈRE, Irene. El relato fantástico: forma mixta de caso y adivinanza. In: ROAS, David. (Org.). Teorías de lo fantástico. Madrid: Arco/Libros S.L., 2001, p. 83-104.

CARPENTIER, Alejo. O barroco e o real maravilhoso; Do real maravilhoso americano. In: A literatura do maravilhoso. Trad. Rubia Moldoni; Sérgio Molina. São Paulo: Editora Revista dos Tribunais; Edições Vértice, 1987, p. 109- 142. 
CARPENTIER, Alejo. Prólogo. In: O reino deste mundo. Trad. Marcelo Tápia. São Paulo: Martins Fontes, 2009, p. 7-12.

CESERANI, Remo. Procedimentos formais e sistemas temáticos do fantástico. In: O fantástico. Trad. Nilton Tripadalli. Curitiba: Ed. UFPR, 2006, p. 67-88.

CHEVALIER, Jean, GHEERBRANT, Alain. Dicionário de símbolos. Trad. Vera da Costa e silva et al. 2 ed. Rio de Janeiro: José Olympio, 1990.

CHIAMPI, Irlemar. O realismo maravilhoso. São Paulo: Perspectiva, 1980.

CHKLÓVSKI, Vítor. A arte como procedimento.In: EIKHENBAUN et al. Teoria da literatura. Formalistas russos. Trad. Ana Mariza Ribeiro Filipousk et al. Porto Alegre: Globo, 1978, p. 39-56.

ESTEVES, Antonio Roberto; FIGUEIREDO, Eurídice. Realismo mágico e Realismo maravilhoso. In: FIGUEIREDO, Eurídice. Conceitos de literatura e cultura. Niterói; Juiz de Fora: EDUFF, EDUFJF, 2010, p. 393-414.

FECHNER, Gustav T. Da anatomia comparada dos anjos. Trad. Paulo Neves. São Paulo: Ed. 34, 1998.

FREUD, Sigmund. O inquietante. In: História de uma neurose infantil (O homem dos lobos): além do princípio do prazer e outros textos. Trad. Paulo César de Souza. São Paulo: Companhia das Letras, 2010, p. 328-376.

FURTADO, Filipe. Fantástico: modo. Disponível em: <http://www.edtl.com. pt>. Acesso em: jun. 2011.

JOSEF, Bella. A máscara e o enigma: a modernidade da representação à transgressão. Rio de Janeiro: Francisco Alves, 1986.

JOSEF, Bella. Uma metáfora da realidade. In: O espaço reconquistado: uma releitura - linguagem e criação no romance hispano-americano contemporâneo. Rio de Janeiro: Paz e Terra, 1993, p. 169-187.

KRISTEVA, Julia. Estrangeiros para nós mesmos. Trad. Maria Carlota Carvalho Gomes. Rio de Janeiro: Rocco, 1994.

MÁRQUEZ, Gabriel García. Um senhor muito velho com umas asas enormes. In: A incrivel história de Cândida Eréndira e sua avó desalmada. Trad. Remy Gorja Filho. São Paulo: Círculo do Livro, [s.d.], p. 9-18.

ROSA, João Guimarães. Um moço muito branco. In: Primeiras estórias. Rio de Janeiro: J. Olympio Ed., 1972, p. 99-104.

SILVEIRA, Nubia. Julio Cortázar, um homem amável que gostava de escrever cartas. Disponível em: <http://www.sul21.com.br/jornal/2011/07>. Acesso em: dez. 2012.

TODOROV, Tzvetan. Definição do fantástico. In: Introdução à literatura fantástica. Trad. Maria Clara Correa Castello. 3. ed. São Paulo: Perspectiva, 2004, p. 29-46. 
138 Número temático: Vertentes do insólito nas literaturas das Américas. A Cor das Letras UEFS, n. 15, 2014 